\title{
Limnological characterisation and phytoplankton seasonal variation in a subtropical shallow lake (Guaiba Lake, Brazil): a long-term study
}

\author{
Caracterização limnológica e variação sazonal do fitoplâncton em um lago raso \\ subtropical (Lago Guaíba, Brasil): estudo de longa duração
}

\section{Rodrigo da Rocha Andrade ${ }^{1}$ and Danilo Giroldo ${ }^{2}$}

\author{
${ }^{1}$ Laboratório de Biologia Aquática e Ecotoxicologia, Departamento Municipal de Água e \\ Esgotos - DMAE, Rua Barão do Cerro Largo, 600, CEP 90850-110, Porto Alegre, RS, Brazil \\ e-mail: rodrigora@dmae.prefpoa.com.br \\ ${ }^{2}$ Programa de Pós-Graduação em Biologia de Ambientes Aquáticos Continentais, Instituto de Ciências \\ Biológicas - ICB, Universidade Federal do Rio Grande - FURG, CEP 96201-900, Rio Grande, RS, Brazil \\ e-mail:dmbgirol@furg.br
}

\begin{abstract}
Aim: to provide a long-term limnological characterisation of a subtropical shallow lake in addition to verifying seasonal differences, including phytoplankton variation. Methods: monthly sampling at sites IP, SJ and MD from 2000 to 2009 to analyse temperature - $\mathrm{T}$; depth - Z; the depth of the euphotic zone $-\mathrm{Z}_{\mathrm{eu}} ; \mathrm{Z}_{\mathrm{eu}} / \mathrm{Z}(\%)$; total suspended solids - TSS; dissolved oxygen - DO; $\mathrm{pH}$; electrical conductivity - EC; $\mathrm{N}-\mathrm{NH}_{3}, \mathrm{~N}-\mathrm{NO}_{2}, \mathrm{~N}-\mathrm{NO}_{3}$; soluble reactive phosphorus - SRP; chlorophyll a - Chl-a and phytoplankton. Results: low values of $\mathrm{Z}$ and $\mathrm{Z}_{\mathrm{eu}}$ characterised the shallow and turbid conditions of lake and corresponded to the contribution of nano-microflagellates (Chlamydomonas sp., Spermatozopsissp., Cryptomonassp. and Rhodomonas sp) and diatoms (Aulacoseira granulata). $\mathrm{Z}_{\text {eu }} \mathrm{IZ}(\%), \mathrm{SRP}$ and Chl-a were significantly different at site IP (meso-eutrophic) compared to sites SJ and MD (eutrophic). Phytoplankton density was also significantly higher at sites $\mathrm{SJ}$ and MD, and the largest relative contribution of Actinastrum sp., Dictyosphaerium sp., Micractinium sp., Monoraphidium sp., Scenedesmus/ Desmodesmus sp. and Euglena sp. corresponded to the most polluted waters at site SJ. The significantly higher $\mathrm{T}\left({ }^{\circ} \mathrm{C}\right)$ in summer corresponded to significantly higher Chl-a as well as a greater richness and density of phytoplankton. Cocconeis sp., Gomphonema $s p$. and Pinnularia sp. (pennated diatoms) were negatively correlated with temperature and were therefore more representative at the three sites in winter. Asterionella formosa was correlated with SRP and vernal blooms were recorded (2000-2001). Planktothrix isothrix and Planktothricoides raciborskii were expressive in the summer/late summer (2004-2005), and were significantly correlated with Chl-a and low SRP in water column. Conclusions: The study corroborated the sensitivity of phytoplankton in characterising different stages of eutrophication at different sites and corresponding watersheds as well as in characterising different seasons in a shallow lake in the subtropical zone of Brazil.
\end{abstract}

Keywords: freshwater, algae, cyanobacteria, eutrofication.

Resumo: Objetivo: prover caracterização limnológica de longa duração e verificar as variaçôes sazonais associadas ao fitoplâncton em um lago raso subtropical no sul do Brasil. Métodos: coletas mensais em três locais (IP, SJ e MD), de 2000 a 2009, para as seguintes análises: temperatura - T; profundidade - Z; profundidade da zona eufótica $-\mathrm{Z}_{\text {eu }} / \mathrm{Z}$ (\%); sólidos suspensos - TSS; oxigênio dissolvido - DO; pH; condutividade - EC; $\mathrm{N}-\mathrm{NH}_{3}, \mathrm{~N}-\mathrm{NO}_{2}, \mathrm{~N}-\mathrm{NO}_{3}$; fósforo solúvel - SRP; clorofila-a - Chl-a e fitoplâncton.

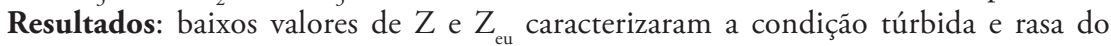
lago e corresponderam à contribuiçáo de Aulacoseira granulata e de flagelados nanomicroplanctônicos dos gêneros Chlamydomonas sp., Spermatozopsis sp., Cryptomonas sp. e Rhodomonas sp dos grupos $\mathrm{X}_{2}$ e $\mathrm{Y} . \mathrm{Z}_{\mathrm{eu}}$ I $(\%)$, SRP e Chl-a foram significativamente menores no ponto IP (meso-eutrófico) comparado aos pontos SJ e MD (eutróficos) onde a densidade do fitoplâncton foi significativamente maior. A maior contribuição relativa de gêneros Actinastrum sp., Dictyosphaerium sp., Micractinium sp., Monoraphidium sp., Scenedesmus/Desmodesmus sp. e Euglena sp. ocorreu nas águas mais poluídas do ponto SJ. $T$ média significativamente maior no verão correspondeu aos maiores valores médios de Chl-a e às maiores riqueza e densidade do fitoplâncton. Diatomáceas penadas (Cocconeis 
sp., Gomphonema sp., Pinnularia sp.) foram negativamente correlacionadas à $\mathrm{T}$ e foram mais representativas no ponto IP, provavelmente em funçáo da maior vazáo do rio Jacuí. Asterionella formosa foi correlacionada ao SRP e floraçóes vernais foram registradas entre 2000 e 2001. Planktothrix isothrix e Planktothricoides raciborskii foram expressivas no verão dos anos de 2004 e 2005 e foram significativamente correlacionadas à Chl-a e associadas à períodos de baixos valores de SRP na coluna d'água. Conclusóes: o estudo confirmou a sensibilidade do fitoplâncton em caracterizar diferentes estágios de eutrofização, bem como, caracterizar diferentes estaçóes do ano em um lago raso subtropical do Brasil.

Palavras-chave: água doce, algas, cianobactérias, eutrofização.

\section{Introduction}

The artificial enrichment of inland waters with nutrients, mainly $\mathrm{N}$ and $\mathrm{P}$, results from sewage discharge from urban, industrial and agricultural regions (Huszar et al., 2005). This process, referred to as eutrophication, has worldwide negative repercussions, causing serious damage to water supplies, notably during treatment for human consumption (Tundisi et al., 2006; McGowan et al., 2012), and changes in aquatic ecosystems and related biological communities, mainly phytoplankton (Istvánovics, 2009).

Phytoplankton represents an important food source for consumers in the pelagic zone of inland waters and is important when assessing water quality (Demir and Atay, 2002), as it acts as a refined sensor of environmental conditions and an accurate indicator of environmental changes (Alvarez-Cobelas et al., 1998). Phytoplankton communities are generally grouped into classes for taxonomic description and for summarising the ecological status of aquatic environments. More recently, phytoplankton functional groups or assemblages, which are groupings of species and genera based on similar sensitivities and tolerances, have been proposed to improve analyses of ecological status and water quality (Reynolds et al., 2002; Reynolds, 2006; Padisák et al., 2006, 2009).

Because the growth of planktonic algae and cyanobacteria is associated with the availability of light and nutrients (Reynolds, 2006), characterisation of phytoplankton is important in describing trophic states and in limnological characterisation (Bellinger and Sigee, 2010), as there is a direct relationship between planktonic dynamics and nutritional levels associated with rivers, dams and lakes (Wetzel, 1983).

Phytoplankton varies in time and space at different scales (Abreu et al., 2010). Models have related phytoplankton variability to nutrient concentrations in inland waters of temperate zones due to the marked seasonality in these regions (Huszar et al., 2005). Several long-term studies have been performed to establish not only patterns of phytoplankton fluctuations but also to verify alterations in these patterns over the years due to hydrological, nutritional and climatic changes (Elliott, 1990; Anneville et al., 2004).

In tropical zones, temperature is not a limiting factor for phytoplanktonic development. Hydrology, the morphometry of water bodies, the use and occupation of watersheds and the frequency, distribution and amount of rain, in addition to the velocity and direction of winds are the most important factors for explaining the occurrence, structure and variation of phytoplankton (Huszar, 1996).

Brazil is a continental country located between the tropical and subtropical zones, and its inland waters are mainly represented by streams, rivers, dams and shallow coastal lakes and lagoons. A study conducted across Brazil showed that the conditions in most of its inland water bodies ranged from mesotrophic to eutrophic (Abe et al., 2006) due to population and economic growth in their corresponding watersheds, which has compromised the quality of water supplies and of water for other uses, mainly due to the occurrence of cyanobacterial blooms (Sant'Anna et al., 2008). Despite its significance for predicting events and the identification of environmental changes, such as those related to climate, hydrology, eutrophication and oligotrophication (Barbosa and Padisák, 2004; Valdes-Weaver et al., 2006), long-term limnological studies in inland waters are scarce in Brazil (Seeliger et al., 2002).

The aim of this study was to provide a longterm limnological characterisation of a subtropical shallow lake from southern Brazil (Guaiba Lake), in addition to verifying seasonal differences, including the influence of quali-quantitative phytoplankton variation. 


\section{Material and Methods}

\subsection{Study area}

Guaiba Lake $\left(29^{\circ} 55^{\prime}-30^{\circ} 24^{\prime}\right.$ S; $51^{\circ} 01^{\prime}-51^{\circ} 20^{\prime}$ W) is located in the Central Depression of Rio Grande do Sul State, Brazil. It extends from the north, in the region of the mouths of rivers that form the Jacuí Delta, to the south, in the Itapua tip, where it flows into Patos Lagoon (Figure 1). The length of the lake is approximately $50.0 \mathrm{~km}$, and its width ranges from 0.9 to $19.0 \mathrm{~km}$. The surface area of the lake is approximately $496 \mathrm{~km}^{2}$ (Nicolodi et al., 2010), and its depth is highly variable, averaging two meters (Bendati et al., 2003).

The rivers that form the Jacuí Delta contribute an average flow of $2,193 \mathrm{~m}^{3} \cdot \mathrm{s}^{-1}$, with $84.6 \%$ of the volume being attributed to the Jacuí River, $7.5 \%$ to the dos Sinos River, 5.2\% to the Caí River and $2.7 \%$ to the Gravataí River. As carriers of sediment, the rivers lose competence toward the broad depositional basin, and the sedimentation rates of coarse material range from 3.5 to 8.3 mm.year ${ }^{-1}$. Guaiba Lake stores a volume of approximately 1.5 billion $\mathrm{m}^{3}$ of water. The river output, water level fluctuations in Patos Lagoon and the direction and intensity of winds are the main factors controlling the flow dynamics in this area. Thus, the lake is not only an extension of the rivers but represents a type of tank that is closely linked to Patos Lagoon (Nicolodi et al., 2010).
In the region of the lake, the climate is humid subtropical (soft mesothermal), categorised as Cfa in Köppen classification (Köppen, 1948). The average minimum and maximum air temperature values range from $14.8{ }^{\circ} \mathrm{C}$ (winter) to $24.2^{\circ} \mathrm{C}$ (summer), and the annual average accumulated precipitation ranges from $1,324 \mathrm{~mm}$ (Livi, 1998) to $1,366 \mathrm{~mm}$ (Vieira and Rangel, 1988).

Guaiba Lake is an important water supply source for the surrounding cities as well as supporting other uses related to economic and commercial activities (Bendati et al., 2003). The most frequent perturbations in this ecosystem are caused by agriculture processes, urbanisation and domestic and industrial sewage discharges (Terra et al., 2009). Five water intake facilities are operated by the Departamento Municipal de Água e Esgotos - DMAE (water and wastewater public works) of Porto Alegre city, three of which have not changed the location of water intake and have been monitored by DMAE since the 1970s. This database constitutes a potential data source for long-term limnological studies and production of information (Andrade and Giroldo, 2010).

\subsection{Sampling and analysis}

Sampling was carried out monthly between January 2000 and December 2009. The samples were collected just below surface, in the water column at three sites $(n=360)$ : Ilha da Pintada - IP; São João/Navegantes - SJ; and Menino Deus - MD
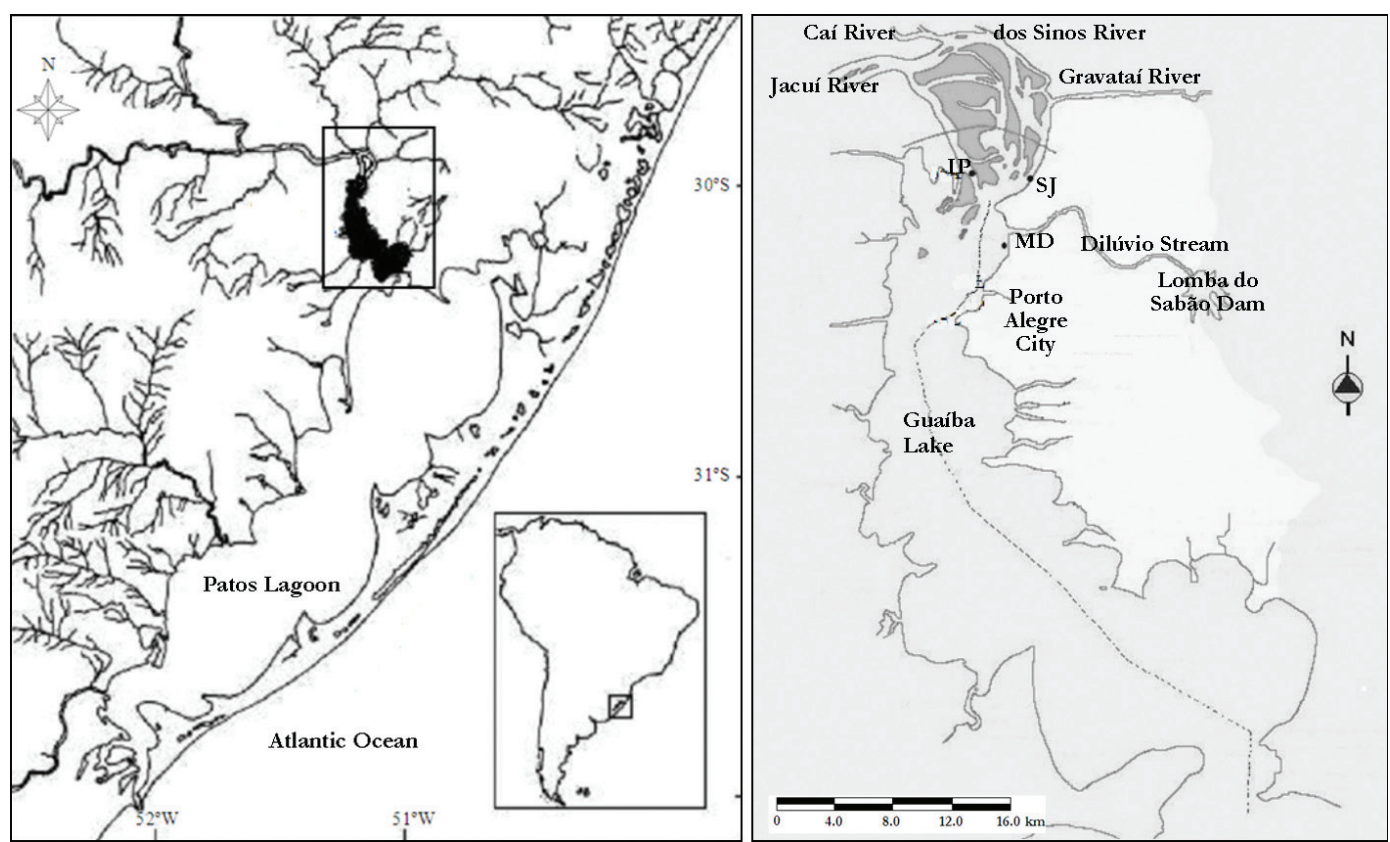

Figure 1. Study area and the IP, SJ and MD sampling sites in Guaiba Lake, Rio Grande do Sul State, Brazil. 
(Figure 1). The field analysis included the measurements of the following parameters: water temperature $\left({ }^{\circ} \mathrm{C}\right)-\mathrm{T}$, using an alcohol thermometer; depth $(m)-Z$, using a graduated weighted rope and transparency $(\mathrm{m})$, using a Secchi disk. The depth of the euphotic zone $-\mathrm{Z}_{\mathrm{eu}}(\mathrm{m})$ was calculated as three times the Secchi disk extinction depth (Cole, 1994). In the laboratory, the following limnological variables were analysed: total suspended matter (mg. $\left.\mathrm{L}^{-1}\right)$ - TSS, via a gravimetric method (ABNT, 1989); dissolved oxygen (mg. $\left.\mathrm{L}^{-1}\right)$ - DO, using the Winkler volumetric method (ABNT, 1988); $\mathrm{pH}$ and electrical conductivity $\left(\mu \mathrm{S} . \mathrm{cm}^{-1}\right)-\mathrm{EC}$, with an electrometric method (ABNT, 1999a, 1999b); and ammonia $-\mathrm{N}-\mathrm{NH}_{3}$, nitrite $-\mathrm{N}-\mathrm{NO}_{2}$, nitrate - $\mathrm{N}-\mathrm{NO}_{3}$ and soluble reactive phosphorus $\left(\mu \mathrm{g} . \mathrm{L}^{-1}\right)-\mathrm{SRP}$, via ion chromatography (USEPA, 1986, 1993). Chlorophyll-a - Chl-a ( $\mu$ g. $\left.\mathrm{L}^{-1}\right)$ determination was carried out following $90 \%$ acetone extraction through spectrophotometric analysis (APHA, 1998).

For phytoplankton analyzes the samples were collected by direct passage of bottles in the subsurface of the water column. During transport (up to 2 hours), the samples remained chilled (8 $\left.{ }^{\circ} \mathrm{C}\right)$ to its preservation in the laboratory. Nonpreserved aliquots were analysed qualitatively under a microscope to survey algae genera, which were identified mainly according Bicudo and Bicudo (1970), Bicudo and Menezes (2005) and Bourrelly (1970, 1972, 1981). Some previously identified species were recorded in this study. Aliquots were preserved with $0.5 \%$ acetic Lugol solution (Vollenweider, 1974) Due to the large number of samples collected and analyses performed, several Brazilian sanitation companies adopt quick protocols for phytoplankton identification and quantification in order to standardize results. Tests between laboratories have shown similar and satisfactory results obtained using counting chambers (Sedgwick-Rafter) compared to the traditional sedimentation method with Utermöhl chambers (Müller et al., 2010). Thus phytoplankton was quantified in Sedgwick-Rafter chambers (length: $50 \mathrm{~mm}$; width: $20 \mathrm{~mm}$; height: $1 \mathrm{~mm}$, volume: $1 \mathrm{~mL}$ ) with the aid of a Whipple reticule coupled to the ocular of a light microscope. The genera were quantified in random fields or bands, and whenever possible, one hundred individuals of a predominant genus were quantified as described in APHA (1998).

The genera were grouped into taxonomic classes according to Van den Hoek et al. (1995). The algae genera that, on average, represented $0.1 \%$ or more of the total density of the samples were considered to represent descriptive taxa (Bicudo et al., 2006).

Descriptive and inferential statistics were determined using the Kruskal-Wallis (K-W) test at a significance level of at least 95\% ( $<<0.05)$ for the set of limnological variables and the data on the richness and density of phytoplankton (log transformation), and all data were grouped into sites and seasons. The data were framed by season according the official calendar of the U.S. Naval Observatory (USNO) for the southern hemisphere, where the summer conventionally starts on December 21, autumn on March 21, winter on June 21 and spring on September 23.

To summarise the obtained data, a matrix of the standardised means ( $z$ scores) of the limnological variables and phytoplankton richness and density data for each season at each site was used to perform a principal component analysis (PCA). Pearson's correlations were provided to investigate the relationships between the densities of descriptive taxa with limnological variables at $\mathrm{p}<0.05$ significance level. All descriptive, inferential and multivariate statistics were obtained using Paleontological statistics software package for education and data analysis - PAST freeware (Hammer et al., 2001).

\section{Results}

\subsection{Limnological characterisation}

The water temperature varied from $10.4^{\circ} \mathrm{C}$ at the SJ site to $29.5^{\circ} \mathrm{C}$ at both the SJ and MD sites (Table 1). IP was the shallowest site, although the average $Z_{\text {eu }}$ values were not significantly different between the sites. However, the $\mathrm{Z}_{\mathrm{eu}} \mathrm{Z}$ ratio (\%) was significantly higher at IP in relation to the other sites, while that at MD was significantly lower in relation to the SJ site. The MD and SJ sites were significantly different from site IP in terms of higher values of $\mathrm{Z}, \mathrm{N}-\mathrm{NO}_{2}, \mathrm{SRP}$ and $\mathrm{Chl}$-a and lower values of $\mathrm{pH}$ and $\mathrm{DO}$. The $\mathrm{SJ}$ and MD sites were significantly different in that a higher value of $\mathrm{Z}$ was observed at the MD site, while higher values of the $\mathrm{Z}_{\mathrm{eu}} / \mathrm{Z}$ ratio (\%), TSS, EC and $\mathrm{N}-\mathrm{NH}_{3}$ were found at the SJ site. On the other hand, the highest concentration of $\mathrm{N}_{-} \mathrm{NO}_{3}$ was detected at the $\mathrm{MD}$ site, which was not significantly higher at the IP and SJ sites, while the Chl-a values were significantly lower at site IP, by almost two times, in relation to sites $\mathrm{SJ}$ and MD. 


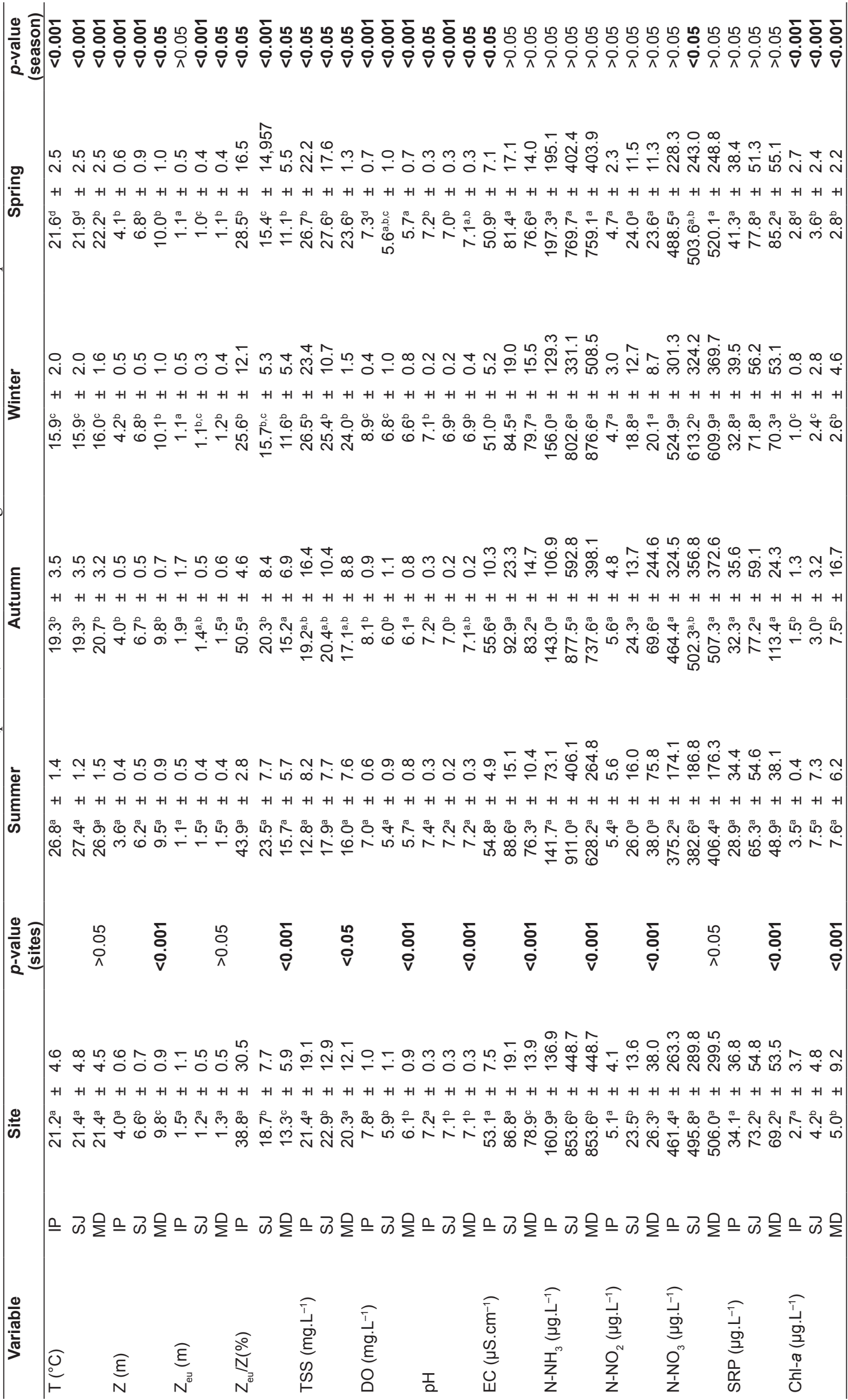


With respect to seasonal limnological variation (Table 1), there were significant differences between the average temperatures detected in the four seasons at site IP. The autumn and spring average $T$ values were significantly different on the sites IP and SJ. On the other hand, the average value of $\mathrm{Z}$ was significantly lower in summer for the three sites. The $Z_{\text {eu }} / Z$ ratio (\%) was not significantly different between summer and autumn for the IP and MD sites. Similar to the seasonal average temperatures at site IP, DO showed values that were significantly higher in winter than summer. At the SJ site, the average dissolved oxygen in spring was not significantly different from that in the other seasons, whereas at the MD site, the average DO was significantly higher only in winter. The average $\mathrm{pH}$ values were substantially and significantly higher in summer for the three sites, whereas the variables $\mathrm{EC}, \mathrm{N}-\mathrm{NH}_{3}, \mathrm{~N}-\mathrm{NO}_{2}, \mathrm{~N}-\mathrm{NO}_{3}$ and SRP showed almost no significant differences in terms of the average seasonal variations, except that EC was significantly lower in summer at the IP site, and $\mathrm{N}-\mathrm{NO}_{3}$ was significantly lower in summer compared to winter at the SJ site. The average values of Chl-a presented a directly proportional correspondence to temperature and an inversely proportional correspondence to DO at site IP, whereas at the SJ and MD sites, only the summer average values of Chl-a were significantly higher in relation to other seasons.

\subsection{Phytoplankton}

Two hundred and fourteen taxa of planktonic algae and cyanobacteria were inventoried, with one hundred ninety-eight being identified to the genus level and the others to the suprageneric level $(7.4 \%)$. The most representative taxonomic classes in terms of richness were Chlorophyceae (30.8\%) and Bacillariophyceae (24.8\%), followed by Cyanophyceae (13.6\%), Chrysophyceae (9.3\%), Euglenophyceae $(7.0 \%)$ and Zygnematophyceae (6.5\%). Cryptophyceae represented $2.3 \%$ of the observed richness, while the other classes each contributed $1.4 \%$ of the richness (Dinophyceae, Prasinophyceae, Raphidophyceae and Xanthophyceae). The survey quantified one hundred eighty-four taxa for site IP, one hundred seventy-nine for site MD and one hundred sixtyfive taxa for site SJ (Figure 2). The richness of class Chlorophyceae was slightly higher at the IP and MD sites in relation to the SJ site. On the other hand, the absolute and relative contribution of Chrysophyceae was lower, while the relative contribution of Bacillariophyceae was higher at SJ in relation to the IP and MD sites. When the average sampled richness was considered, rather than the cumulative results of the inventory, it was found to be significantly higher at the SJ and MD sites than at site IP $(\mathrm{p}<0.001)$. For all samples, the average density at site IP was 354 ind. $\mathrm{mL}^{-1}$, which was significantly lower than the average density at SJ (732 ind. $\mathrm{mL}^{-1}$ ) and MD (609 ind. $\mathrm{mL}^{-1}$ ). The inferential tests confirmed that the average phytoplanktonic richness at site IP was significantly higher in summer compared to the other seasons (Figure 2). At the SJ site, the average richness in autumn and winter was significantly lower than the richness in spring and summer, while at the MD site, it was only possible to confirm that the richness in autumn was significantly lower than the richness in summer. In turn, the average summer densities at the IP and SJ sites were significantly higher compared to the other seasons, while at site $\mathrm{MD}$, it was only possible to conclude that the winter densities were significantly lower than the densities in the other seasons.

The most representative taxa belonged to seven taxonomic classes (Table 2). The IP site stood out due to the major contributions of Bacillariophyceae genera (Aulacoseira sp., Cocconeis sp., Gomphonema sp., Pinnularia sp., unidentified diatoms), in the density of phytoflagellates from the Cryptophyceae (Cryptomonas sp.) and Euglenophyceae (Euglena sp., Strombomonassp., Trachelomonas sp.) classes and based on the higher density of phytoflagellates from class Chlorophyceae, such as Eudorina sp., Spermatozopsis sp. (Spermatozopsis exsultans Korshikov) and colourless flagellates of class Chrysophyceae (Cladomonas sp., Rhipidodendron sp.).

The SJ and MD sites stood out in showing the lowest relative contribution among the identified genera of Bacillariophyceae, except for Asterionella sp. (Asterionella formosa Hassal), in the higher relative contribution of Chlorophyceae (Actinastrum sp., Dictyosphaerium sp., Micractinium sp, Monoraphidium sp., Scenedesmus / Desmodesmus $s p$.) and due to the higher density of Cryptophyceae and Euglenophyceae. The genera Cyclotella sp. and Nitzschia sp. as well as phytoflagellates of different classes, such Peridiniales NI, Bicosoeca sp., Chromulina sp. Synura sp. and Rhodomonas $s p$. (Rhodomonas minuta v. nannoplanctica Skuja), were more expressive at the MD site in relation to SJ and IP sites.

The highest phytoplankton density (Figure 3) generally occurred in January (summer), while 


\section{Richness}
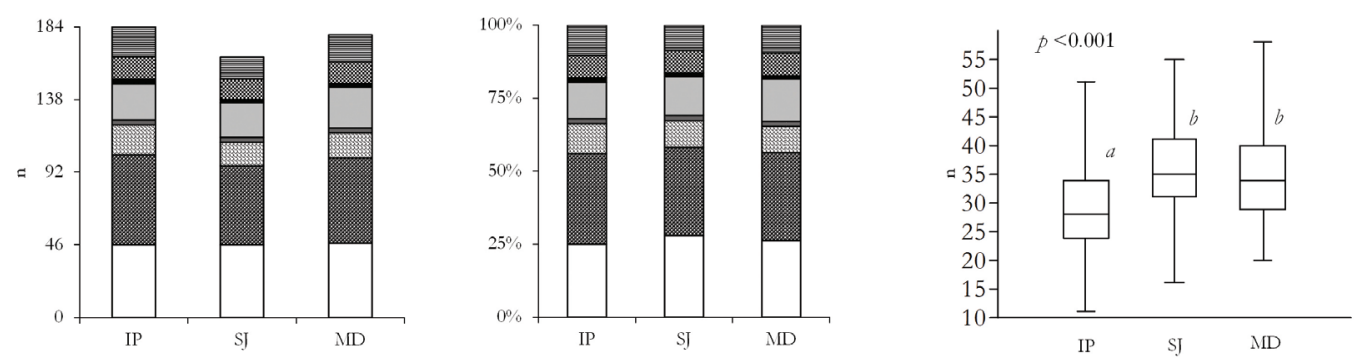

IP

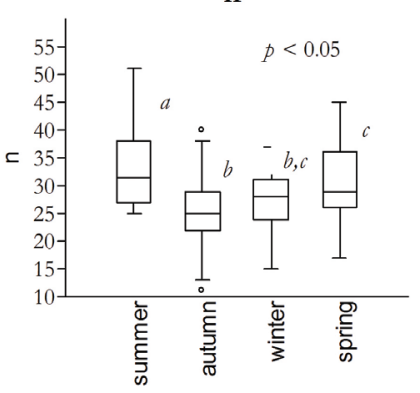

SJ
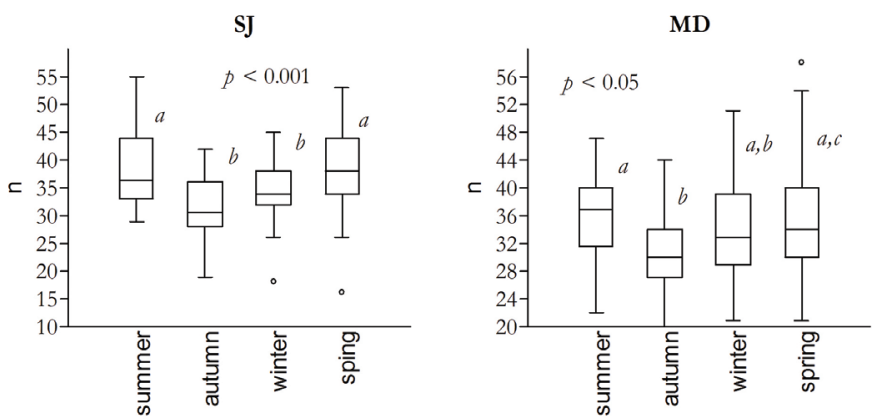

Density
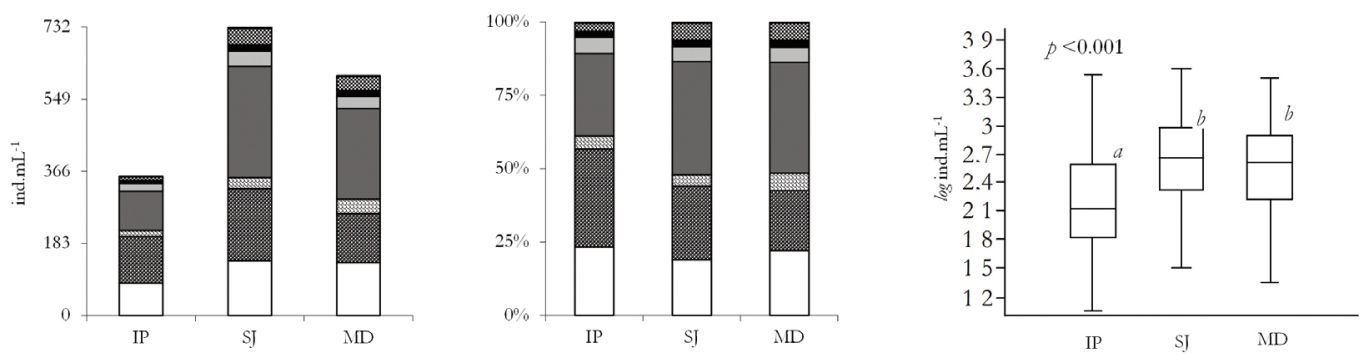

IP

SJ
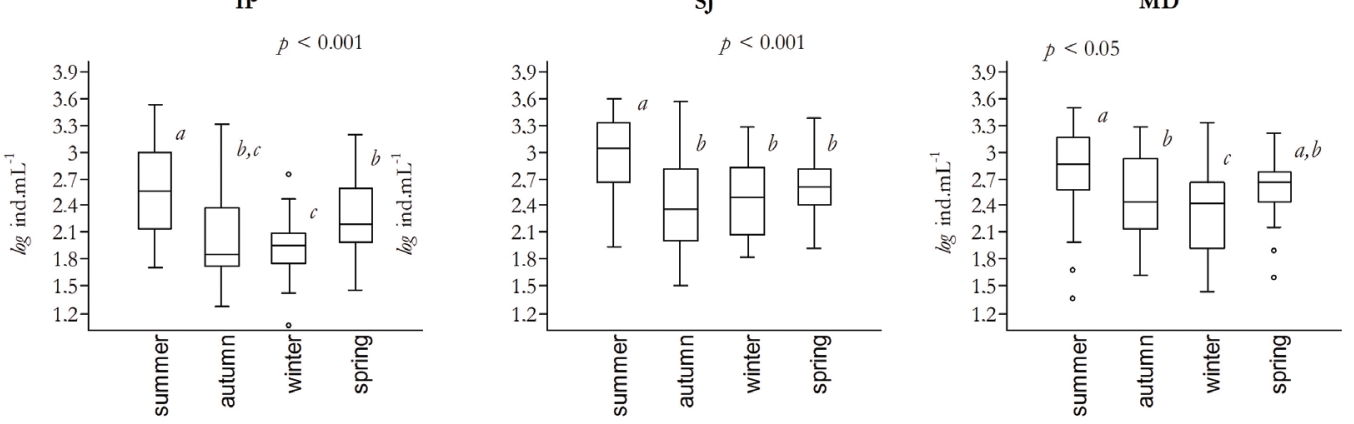

$$
\begin{aligned}
& \square \text { Bacillariophyceae } \text { Chlorophyceae } \text { 圈 Chrysophyceae } \square \text { Cryptophyceae } \\
& \square \text { Cyanophyceae Dinophyceae } \quad \text { Euglenophyceae 目 Others }
\end{aligned}
$$

Figure 2. Absolute and relative contributions of taxonomic classes and sites and seasonal variations of richness and density of phytoplankton in Guaiba Lake; different letters indicate significant differences of values at $p<0.05$.

the lowest density occurred in July (winter) within the annual cycles. Almost all of the most representative taxonomic classes experienced an increase in density towards summer in the annual cycles, whereas the most representative groups in winter were Bacillariophyceae and Cryptophyceae. Some density increments, which were generally less than the annual summer increases, were observed in spring at all sites. In 2000, a considerable contribution of Bacillariophyceae at site $S J$ it was observed in late winter (September), when the density of diatoms was 1,863 ind. $\mathrm{mL}^{-1}$, mainly contributed by Asterionella sp., and there were low increments of density between winter and spring. 

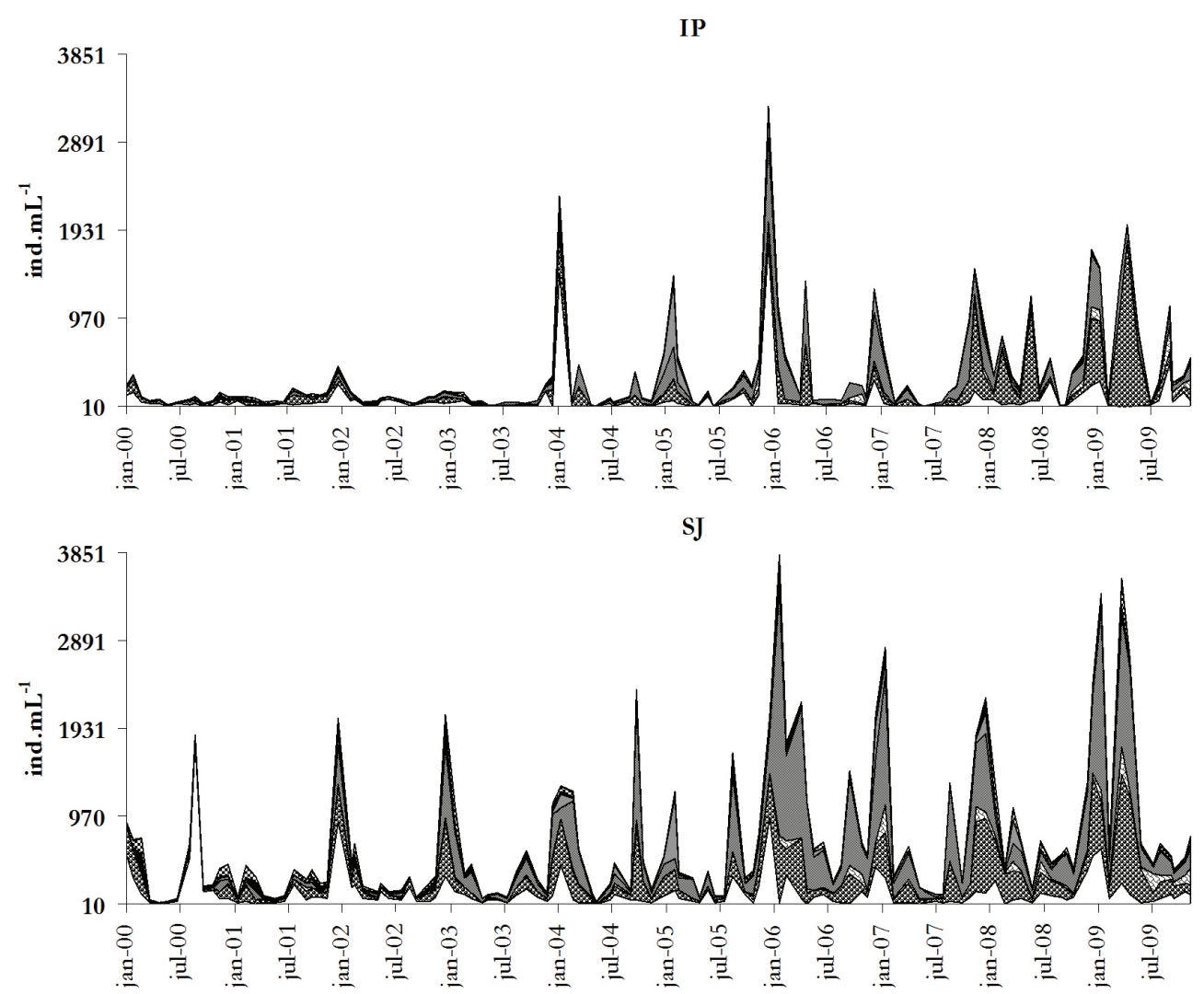

MD

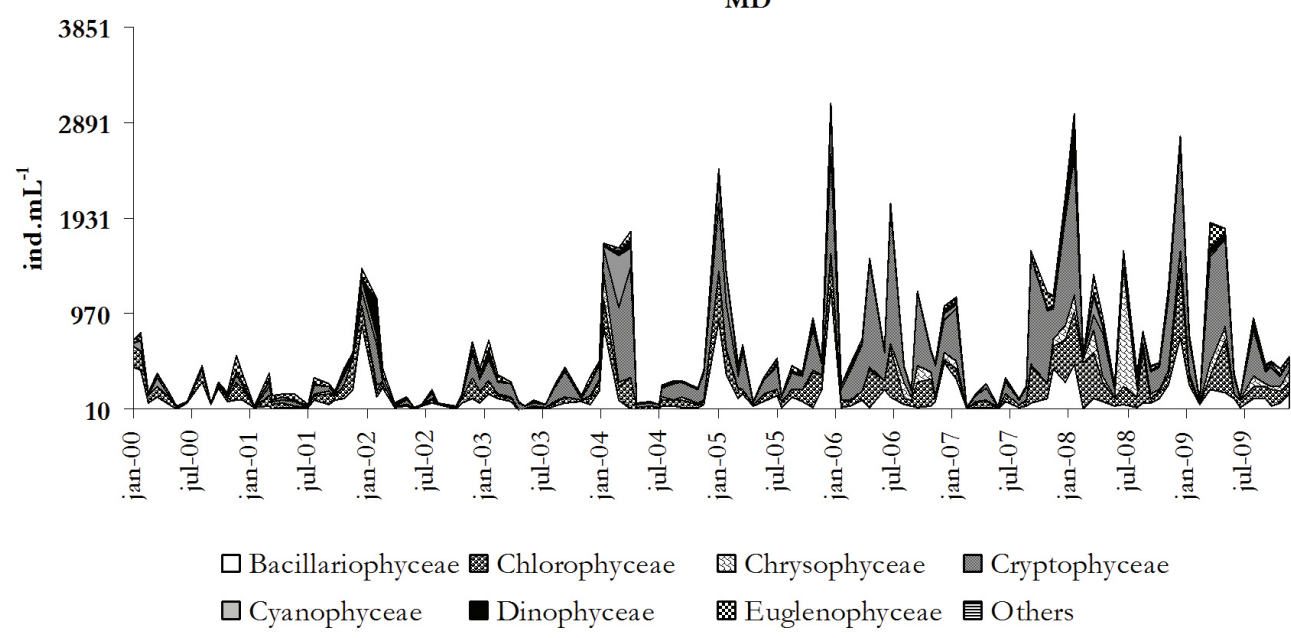

Figure 3. Temporal profile of density classes of phytoplankton in Guaiba Lake.

In that year, Asterionella sp. represented $70 \%$ of the phytoplanktonic density $\left(283\right.$ ind. $\left.\mathrm{mL}^{-1}\right)$ at the MD site.

In the summer months and early fall of 2004 , there was a greater contribution of cyanobacteria belonging to the taxa Planktothrix/Planktothricoides , i.e., P. isothrix (Skuja) Komárek \& Komárková and P. agardhii (Gomont) Anagnostidis \& Komárek as well as Planktotricoides raciborskii (Woloszynska) Suda \& Watanabe at sites SJ and MD, and in 2005, a similar situation was observed at sites IP and SJ.
In January 2007, cyanobacteria also contributed to the phytoplankton densities at the three sites, and in 2008, the contribution of cyanobacteria persisted until early autumn at the MD and SJ sites.

\subsection{Relationship between phytoplankton and limnological variables}

The PCA accounted for $85.5 \%$ of the variation in the analysed system (Figure 4). The first axis (56.9\%) represented the longitudinal distribution of sites, and it was positively and significantly related 


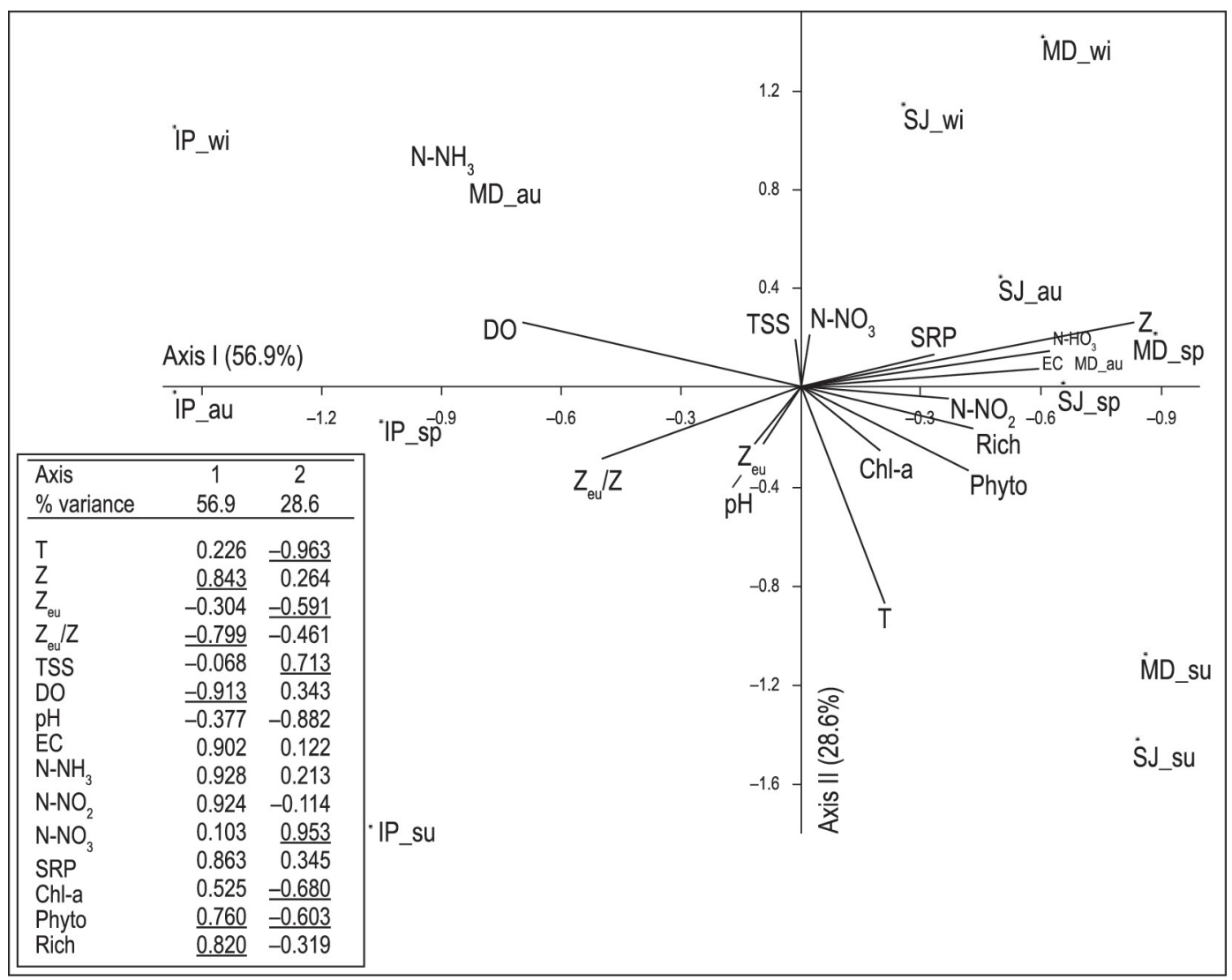

Figure 4. Biplot of seasonal units at the IP, SJ and MD sites and variable vectors on the first two PCA axes; su - summer; sp - spring; wi - winter; au- autumn; in box: underlined numbers $\mathrm{p}<0.05$, bold numbers $\mathrm{p}<0.001$.

to EC, N-NH$H_{3}, \mathrm{~N}-\mathrm{NO}_{2}$ and SRP, with higher concentrations of Chl-a being associated with a higher density and richness of phytoplankton at the SJ and MD sites, regardless of the season. On the negative side, the first axis was correlated with shallower and more transparent waters, together with lower DO and Chl-a concentrations as well a lower richness and density of phytoplankton at site IP. The second axis (28.6\%) represented the seasonal variation in limnological variables and the density and richness of phytoplankton. The temperature increase toward the negative side of axis 1 was associated with increased $\mathrm{pH}$ and $\mathrm{Chl}-\mathrm{a}$ values as well as the density and richness of phytoplankton towards the summer months for the three sites considered. At the three sites, the winter season was mainly characterised by low temperatures and higher levels of TSS and DO.

Regarding the composition of genera, it was found that pennated diatoms of the genera Asterionella $s p .(\mathrm{r}=-0.166)$, Encyonema sp $(\mathrm{r}=-0.116) .$, Eunotia $s p .(\mathrm{r}=-0.130)$, Gomphonema sp. $(\mathrm{r}=-0.187)$ and Pinnularia sp. $(\mathrm{r}=-0.161)$ were significantly correlated $(\mathrm{p}<0.05)$ with low temperatures, and among these genera, Asterionella sp. was associated with higher levels of SRP $(r=0.427)$, which were observed at the MD and SJ sites compared to site IP (Table 2). Centric diatoms (Aulacoseira sp., $\mathrm{r}=0.441$; Cyclotella sp., $\mathrm{r}=0.367)$ and stellate filaments of Nitzschia sp. (Nitzschia fruticosa Hustedt; $r=0.309$ ) were associated with elevated temperatures. Among the observed phytoflagellates, the genera Trachelomonas sp. and Euglena sp. (Euglenophyceae) were correlated with the deeper waters $(\mathrm{r}=0.246$ and 0.306$)$, rich in $\mathrm{N}-\mathrm{NH}_{3}$ $(\mathrm{r}=0.342$ and 0.381$)$, with high EC $(\mathrm{r}=0.295$ and 0.395$)$ and low DO levels $(r=-0.472$ and -0.398). Between green flagellates, Chlamydomonas sp. $(\mathrm{r}=0.350)$, Eudorina sp. $(\mathrm{r}=0.365)$ and Pandorina sp. $(\mathrm{r}=0.367)$ were positively associated with temperature. However, only Chlamydomonas $s p$. were more associated with $\mathrm{Z}_{\mathrm{eu}}(\mathrm{r}=0.265)$ and higher EC $(\mathrm{r}=0.302)$ and Chl-a values $(\mathrm{r}=0.336)$. Spermatozopsis exsultans was most strongly associated with a greater $Z_{\text {eu }}(r=0.582)$. The most representative genera in terms of biomass (Chl-a) were Aulacoseira sp. $(r=0.256)$ and Cyclotella sp. $(r=0.250)$, Monoraphidium sp. $(r=0.204)$, Chlamydomonas sp. 
Table 2. Average relative contribution (\%) of descriptive taxa to the total density of phytoplankton at the IP, SJ and MD sites in Guaiba Lake; NI - unidentified.

\begin{tabular}{|c|c|c|c|}
\hline BACILLARIOPHYCEAE & IP & SJ & MD \\
\hline Asterionella sp. & $<0.1$ & 3.1 & 0.8 \\
\hline Aulacoseira sp. & 7.8 & 4.0 & 5.7 \\
\hline Cocconeis sp. & 0.3 & 0.2 & 0.1 \\
\hline Cyclotella sp. & 3.9 & 3.2 & 5.4 \\
\hline Encyonema sp. & 0.1 & 0.1 & 0.1 \\
\hline Pennate diatom NI & 1.3 & 0.6 & 0.8 \\
\hline Eunotia sp. & 0.1 & 0.1 & 0.1 \\
\hline Gomphonema sp. & 1.0 & 0.5 & 0.6 \\
\hline Melosira sp. & 0.6 & 0.3 & 0.4 \\
\hline Navicula sp. & 1.0 & 0.8 & 1.0 \\
\hline Nitzschia sp. & 5.8 & 5.5 & 6.0 \\
\hline Pinnularia sp. & 0.3 & 0.2 & 0.2 \\
\hline \multicolumn{4}{|l|}{ CHLOROPHYCEAE } \\
\hline Actinastrum sp. & 0.1 & 0.5 & 0.4 \\
\hline Ankistrodesmus sp. & 0.3 & 0.6 & 0.3 \\
\hline Chlamydomonas sp. & 7.6 & 8.1 & 7.1 \\
\hline Crucigenia sp. & 0.4 & 0.4 & 0.6 \\
\hline Dictyosphaerium sp. & 0.2 & 0.8 & 0.6 \\
\hline Eudorina sp. & 0.4 & 0.2 & 0.2 \\
\hline Golenkinia sp. & 0.2 & 0.1 & 0.1 \\
\hline Micractinium sp. & 0.2 & 1.3 & 1.1 \\
\hline Monoraphidium sp. & 2.6 & 3.4 & 3.2 \\
\hline Oocystis sp. & $<0.1$ & 0.2 & 0.2 \\
\hline Pandorina sp. & 0.2 & 0.3 & 0.2 \\
\hline Pedinopera sp. & 1.0 & 0.7 & 0.5 \\
\hline Scenedesmus/Desmodesmus sp. & 1.6 & 2.5 & 1.8 \\
\hline Spermatozopsis sp. & 17.9 & 4.6 & 3.5 \\
\hline \multicolumn{4}{|l|}{ DINOPHYCEAE } \\
\hline Peridiniales NI & 2.1 & 2.3 & 2.5 \\
\hline CHRYSOPHYCEAE & IP & SJ & MD \\
\hline Bicosoeca sp. & 2.2 & 1.9 & 2.3 \\
\hline Chromulina sp. & 0.2 & 0.2 & 0.4 \\
\hline Chrysococcus sp. & 0.1 & 0.3 & 0.2 \\
\hline Cladomonas sp. & 0.4 & 0.1 & $<0,1$ \\
\hline Codosiga sp. & 0.4 & 0.1 & 0.4 \\
\hline Dinobryon sp. & 0.1 & 0.1 & 0.1 \\
\hline Mallomonas sp. & 0.7 & 0.8 & 0.8 \\
\hline Rhipidodendron sp. & 0.3 & $<0.1$ & $<0.1$ \\
\hline Synura sp. & 0.1 & 0.4 & 1.7 \\
\hline \multicolumn{4}{|l|}{ CRYPTOPHYCEAE } \\
\hline Chroomonas sp. & 0.7 & 0.3 & 0.7 \\
\hline Cryptomonas sp. & 27.4 & 38.3 & 37.0 \\
\hline Rhodomonas sp. & 9.3 & 8.6 & 13.1 \\
\hline \multicolumn{4}{|l|}{ CYANOPHYCEAE } \\
\hline Anabaena sp. & 0.8 & 0.4 & 0.3 \\
\hline Merismopedia sp. & 0.8 & 1.4 & 0.9 \\
\hline Planktothrix/Planktothricoides sp. & 3.3 & 2.2 & 2.8 \\
\hline Pseudanabaena sp. & 0.3 & 0.5 & 0.5 \\
\hline \multicolumn{4}{|l|}{ EUGLENOPHYCEAE } \\
\hline Euglena sp. & 0.5 & 1.9 & 1.7 \\
\hline Phacus sp. & 0.1 & 0.1 & 0.1 \\
\hline Strombomonas sp. & 0.2 & 0.3 & 0.3 \\
\hline Trachelomonas sp. & 1.8 & 3.1 & 3.3 \\
\hline
\end{tabular}

( $r=0.336)$, Mallomonassp. $(r=0.281)$, Cryptomonas $s p .(r=0.341)$ and dinoflagellates - PeridNI $(r=0.290)$. The higher correlation of Planktothrix/ Planktothricoides (Planktothrix isothrix and Planktothricoides raciborskii) with Chl-a $(r=0.509)$ was influenced by summer peaks, mainly in 2004 (MD and SJ) and 2005 (IP and SJ).

\section{Discussion}

The trophic status of a water body can roughly be assessed based on information regarding the concentration of the limiting nutrient, chlorophyll-a and transparency, which indicate algal biomass, sediment resuspension and penetration of light into the water. The most widely accepted limits of these variables have been suggested by OECD (1982) to characterise the trophic categories (oligotrophic, mesotrophic and eutrophic) of inland waters (Istvánovics, 2009). In this study, the ranges of the mean to maximum values of Chl-a at the IP, SJ and MD sites were found to be 2.7-26.0, 4.2-37.6 and 5.0-88.9 $\mu \mathrm{g} . \mathrm{L}^{-1}$, respectively. According to OECD (1982), average values between 2.5 and $8.0 \mu \mathrm{g} . \mathrm{L}^{-1}$ characterise mesotrophic waters, while maximum values above $25.0 \mu \mathrm{g} . \mathrm{L}^{-1}$ characterise eutrophic waters. The average SRP values were also higher than the limit of $35.0 \mu \mathrm{g} . \mathrm{L}^{-1}$ of total phosphorus for mesotrophic waters at the SJ and MD sites, characterising these sites as eutrophic. Additionally, the average Secchi disk values $\left(Z_{\text {eu }} / 3\right)$ obtained at the three sites were less than $3.0 \mathrm{~m}$, typical of eutrophic waters.

The lowest average SRP value obtained at the IP site $\left(34.1 \mu \mathrm{g} . \mathrm{L}^{-1}\right)$ was coincident with the lowest average values recorded for EC $\left(53.1 \mu \mathrm{S} . \mathrm{cm}^{-1}\right)$, dissolved inorganic nitrogen (mainly in the form of N-NH$H_{3}$; $\left.160.9 \mu \mathrm{g} . \mathrm{L}^{-1}\right)$, Chl-a $\left(2.7 \mu \mathrm{g} . \mathrm{L}^{-1}\right)$ and the total phytoplankton density $\left(354\right.$ ind. $\mathrm{mL}^{-1}$ ). This set of parameter values characterised this site as "less eutrophic" in relation to SJ and MD, which was also corroborated by the higher average DO (7,8 mg. $\left.\mathrm{L}^{-1}\right)$ and $\mathrm{Z}_{\mathrm{eu}} / \mathrm{Z}(38.8 \%)$ values observed at the IP site in relation to sites SJ and MD. These data and the limits established by the OECD suggest meso-eutrophic conditions for site IP and truly eutrophic conditions for sites SJ and MD in Guaiba Lake.

The trophic statuses of the three sites investigated in this study were associated with their locations in different watersheds. The IP site is influenced by the flow of the Jacuí River, which is the largest tributary to the lake, approximately $1,850 \mathrm{~m}^{3} \cdot \mathrm{s}^{-1}$, and whose basin is predominantly occupied by 
agricultural activities (Noronha, 1998; Faria and Lersch, 2001). The trophic statuses determined at the MD and SJ sites corresponded to the higher occupancy of these basins in terms of population. Thus, the water quality at the latter two sites has become more eutrophic, whether due to higher concentrations of nutrients and chlorophyll-a or the greater density of phytoplankton. This finding corroborates the idea that the structure and development of phytoplankton are influenced by the hydrology and the use and occupation of the corresponding watershed, as observed in the inland waters in tropical zones of Brazil (Huszar, 1996).

In this study different taxonomic classes of phytoplanktonic algae had significantly higher density in eutrophic points (MD and SJ) compared to meso-eutrophic point, as well as, it had significantly higher density in the summer compared to other seasons. This finding revealed that the traditional classification of phytoplankton taxonomic may be a limited tool in limnological assessment of lakes and rivers. Reynolds et al. (2002) has proposed of a functional classification scheme for the phytoplankton species that has been tested and it is considered as an important predictive tool. This classification scheme brings species with similar morphology, physiology, and ecology together into functional groups named using alphanumerical characters. Since then, tests using phytoplankton have been constantly improved to qualify the environments (Padisák et al., 2006).

Regarding the composition of phytoplankton, diatom genera, such as Cocconeis sp., Gomphonema $s p$., Pinnularia $s p$. and unidentified diatoms, referred to as DiaPenNI, showed a higher relative contribution at the IP site in relation to the others. According to Padisák et al. (2009), some pennated diatoms belonging to the MP functional group are indicators of river flows, which agrees with the hydrodynamic characterisation of site IP, which is influenced by the greatest river flow. In contrast, the genus Asterionella sp. showed a higher mean density at sites SJ and MD. This exception agrees with studies showing that blooms of $A$. formosa are associated with higher phosphorus availability in certain periods of seasonal variation, especially the vernal period in temperate zones of the Earth (Sommer, 1988). A. formosa belongs to the C functional group, indicating eutrophic small and medium-sized lakes that are sensitive to the onset of stratification (Padisák et al., 2009).

Despite exhibiting significantly higher average TSS $\left(22.9 \mathrm{mg} \mathrm{L}^{-1}\right)$, EC $\left(86.8 \mu \mathrm{S} . \mathrm{cm}^{-1}\right)$ and $\mathrm{N}-\mathrm{NH}_{3}$
(853.6 $\mu \mathrm{g} . \mathrm{L}^{-1}$ ) values, the SJ site showed no significantly different values regarding Chl-a or the richness and density of phytoplankton in relation to the MD site. The $S J$ site is located downstream from the mouth of the Gravataí River, which is a tributary presenting a lowest flow rate (approximately 59 $\mathrm{m}^{-3} \cdot \mathrm{s}^{-1}$ ), highest human population density and highest concentrations of pollutants in the region (Noronha, 1998). The apparently most polluted condition observed at the SJ site in relation to the MD and IP sites coincided with the greatest relative contribution of Chlorophyceae genera such as Actinastrum sp., Ankistrodesmus sp., Dictyosphaerium sp., Micractinium sp., Monoraphidium sp., and Scenedesmus/Desmodesmus sp. and the greater relative contribution of phytoflagellate genera belonging to class Cryptophyceae (Cryptomonas sp.) and Euglenophyceae (Euglena sp.) to the density of phytoplankton. Unicellular and coenobial/colonial green algae belonging the $\mathrm{F}, \mathrm{X}_{1}$ and $\mathrm{J}$ functional groups are associated with shallow eutrophic systems (Padisák et al., 2009), while cryptomonads ( $\mathrm{X}_{2}$ and Y groups) are linked to the availability of nutrients (Klaveness, 1988) and euglenoids (W group) to the availability of organic matter (Tell et al., 2005).

The increasing values of Chl-a, phytoplankton density, EC, and some forms of nutrients at the IP, $\mathrm{MD}$ and SJ sites coincided with the water quality index (WQI) values observed over time in a longterm study (2000-2009) by Andrade et al. (2012), in which the mean scores (and ranges) were found to be 69.8 (regular), 51.3 (regular/bad) and 49.2 (bad) for these sites, respectively. This comparison confirmed the sensitivity of the composition and density of phytoplankton in indicating different trophic conditions as well as the different water quality conditions observed at the sites investigated in the present study.

For the three sites, there were higher relative densities of the genera Aulacoseira sp., Chlamydomonas sp., Spermatozopsissp., Cryptomonas $s p$. and Rhodomonas sp. According to Reynolds (2006), Aulacoseira species (P group, Aulacoseira granulata v. angustissima (O. Müller) Simonsen) are meroplanktonic (spending one phase of life in the sediment and another in the pelagic zone) and can be significant in shallow lakes under meso-eutrophic conditions when exposed to wind and wave action, as occurs in the investigated lake (Nicolodi et al., 2010). Nano-microplanktonic flagellates $\left(X_{2}\right.$ and $\mathrm{Y}$ groups) belonging to the genera mentioned above are collectively common and constitute 
representative assemblages in shallow lakes whose main strategy is rapid growth.

The high diversity of Chlorophyceae and Bacillariophyceae at the three sites was in accord with the findings of a short-term study showing that say these groups are more representative of the diversity observed at the mouths of the rivers that form the delta of the Jacuí River, upstream of Guaiba Lake (Rodrigues et al., 2007).

Long-term studies have been performed to establish seasonal patterns in phytoplankton and to verify variations over the years due to hydrological, nutritional and climatic changes (Anneville et al., 2004). In this study, the long-term data obtained were useful for verifying significant seasonal patterns in limnological conditions as well as phytoplankton richness and density. If the temperature in the tropical zone is not a limiting factor for the development of phytoplankton (Huszar, 1996), the same cannot be said for Guaiba Lake, which is situated in the subtropical zone of Brazil, considering that the average density in winter recorded in this long-term study was significantly lower than the average density in summer.

The significantly higher temperatures in summer coincided with significantly higher values of Chl-a, $\mathrm{pH}$, phytoplankton density and $\mathrm{Z}_{\mathrm{eu}} / \mathrm{Z}$ (\%), and significantly lower values of Z, TTS and DO. The increased water temperature in summer is related to the more intense solar radiation that occurs in the subtropical region of Brazil in this season (Mendonça and Danni-Oliveira, 2007) because the variation in irradiance is cyclical and is inversely proportional to latitude. This pattern characterises temperature as a determining factor in the seasonal abundance and the distribution and geographic variation of phytoplankton (Reynolds, 1988). Because light availability is crucial to the development of phytoplankton, some classes of algae experienced a density increase in summer in Guaiba Lake, and only seven genera were negatively correlated with water temperature, five of which were pennated diatoms (Asterionella sp. Encyonema sp. Eunotia sp. Gomphonema sp. Pinnularia sp.), and two were colonial flagellates of class Chrysophyceae (Cladomonas sp. Synura sp.).

Regarding the reduced $\mathrm{Z}$ in the lake in summer, the long-term study by Andrade and Giroldo (2010) revealed a significant correlation of $\mathrm{Z}$ with the volume of rain. The authors stated that the thermal/ climatic seasonality of Guaiba Lake is accompanied by hydrological seasonality and that summer is the season showing the lowest values of accumulated precipitation and depth.

In contrast to what has been demonstrated in subtropical reservoirs (Rodrigues et al., 2005), the development of phytoplankton in Guaiba Lake in summer was not followed by an increase in TSS, but by increased transparency. Similar behaviour has been observed in subtropical Brazilian rivers, where abiogenic turbidity during rainy periods in winter and spring overcomes the biogenic turbidity caused by the development of phytoplankton in summer (Devercelli, 2006).

The temporal profile of the phytoplanktonic density by class shows that the peak densities of Chlorophyceae, Bacillariophyceae (centric diatoms: Aulacoseirasp., Cyclotella sp.) and Cryptophyceae in summer were most likely associated with low water levels subjected to turbulence caused by winds, as usually occurs in the lake (Nicolodi et al., 2010). The expressive contribution of cyanobacteria, especially in 2004 (MD and SJ sites) and 2005 (IP and SJ sites), characterised by development of Planktothrix isothrix and Planktothricoides raciborskii were associated with anomalies in precipitation (La Niña) and high values of chlorophyll-a $(r=0.509, p<0.01)$ according to Andrade and Giroldo (2010) as well as high transparency and temperatures (Maizonave et al., 2009). According to Padisák et al. (2009) P. isothrix (referred to as P. mougeotii) belongs to $\mathrm{R}$ codon. Such assemblages are associated with stratification and occur in the metalimnion or upper hypolimnion of oligomesotrophic lakes. Because lower phosphorus levels occur in the summer and the main source of this element during periods of high hydraulic retention (due to low rainfall in anomalous periods) should be the sediment, it is likely that these species ( $P$. isothrix and Planktothricoides raciborskii) explore the bottom to assimilate and store phosphorus (Paerl, 1988). In fact, short term study conducted by Ribeiro et al. (2012) in a south bay of Guaiba Lake, between spring 2011 and summer 2012 has suggested that changes in rainfall patterns due to La Niña can influence the environment, increasing transparency and recruiting cyanobacterial inocula deposited in layers more enriched. The study also pointed out that there was thermal stratification prior to the beginning of summer Planktotricoides raciborskii bloom.

The antagonic conditions in winter confirmed that low temperatures and high turbidity (high TSS) inhibit the development of phytoplankton in Guaiba Lake, which confirms that there are seasonal 
limnological conditions in this lake, associated with variations in phytoplankton.

The results of this study show the potential of phytoplankton regarding differentiating between trophic state conditions and, thus, for assisting in the limnological characterisation of inland waters. The composition and density of phytoplankton should also be helpful in diagnosing the quality of waters that are subject to eutrophication and the development of cyanobacteria, as occurs in many lakes and rivers in Brazil (Abe et al., 2006; Sant'anna et al., 2008). The subtropical inland waters in the subtropical region of Brazil suffer abnormal rain fluctuations related to the El Niño southern oscillation (Abreu et al., 2010; Andrade and Giroldo, 2010). The occurrence of this type of pattern alters the seasonal fluctuations of phytoplankton, corroborating the significance of long-term studies to better characterise and understand phytoplankton ecology.

\section{Acknowledgements}

The authors are indebted to professors Paulo C. Abreu from the Universidade Federal do Rio Grande (FURG), Lezilda C. Torgan from the Fundação Zoobotânica do Rio Grande do Sul (FZB/RS) and referees of Acta Limnologica Brasiliensia for the useful suggestions provided throughout the original manuscript.

\section{References}

ABE, DS., TUNDISI, JG., MATSUMURA-TUNDISI, T., TUNDISI, JEM., GALLI, CS., TEIXEIRASILVA, V., AFONSO, GF., VON HAEHLING, PHA., MOSS, G. and MOSS, M. 2006. Monitoring of inland surface water quality and trophic potential in a continental-scale in Brazil by hydroplane. In TUNDISI, JG., TUNDISI, TM. and GALLI, CS., orgs. Eutrophication in South America: causes, consequences and technologies for management and control. São Carlos: International Institute of Ecology. p. 225-239.

ABREU, PC., BERGESCH, M., PROENÇA, LA., GARCIA, CAE. and ODEBRECHT, C. 2010. Short- and long-term chlorophyll-a variability in the shallow microtidal Patos Lagoon Estuary, Southern Brazil. Estuaries and Coasts, vol. 33, no. 2, p. 554569. http://dx.doi.org/10.1007/s12237-009-9181-9

ALVAREZ-COBELAS, M., REYNOLDS, CS., SANCHEZ-CASTILLO, P. and KRISTIANSEN, J. 1998. Phytoplankton and trophic gradients. Dordrecht: Kluwer Academic Publishers. (Developments in Hydrobiology, no. 129).
American Public Health Association - APHA. 1998. Standard methods for the examination of water and wastewater. Washington.

ANDRADE, RR. and GIROLDO, D. 2010. Consideraçóes sobre a variação temporal do fitoplâncton em um ponto amostral do lago Guaiba: estudo de longa duração. Ecos Técnica, no. 3, p. 5-13.

ANDRADE, RR., COLARES, ERC., KRIGGER, SS., MAIZONAVE, CRM. and MORANDI, IC. 2012. Lago Guaiba (RS): índice de qualidade da água-IQA, 2000 a 2009. Ecos Técnica, no. 4, p. 5-14.

ANNEVILLE, O., SOUISSI, S., GAMMETER, S. and STRAILE, D. 2004. Seasonal and inter-annual scales of variability in phytoplankton assemblages: comparison of phytoplankton dynamics in three peri-alpine lakes over a period of 28 years. Freshwater Biology, vol. 49, no. 1, p. 98-115. http://dx.doi. org/10.1046/j.1365-2426.2003.01167.x

Associação Brasileira de Normas Técnicas-ABNT. 1988. NBR 10559: Águas - Determinação de oxigênio dissolvido - Método idométrico de Winkler e suas modificações. Rio de Janeiro: ABNT.

Associação Brasileira de Normas Técnicas - ABNT. 1989. NBR 10664: Água - Determinação de resíduos (sólidos) - Método gravimétrico. ABNT, Rio de Janeiro.

Associação Brasileira de Normas Técnicas - ABNT. 1999a. NBR 14339: Água - Determinação de $\mathrm{pH}$ - Método eletrométrico. Rio de Janeiro: ABNT.

Associação Brasileira de Normas Técnicas - ABNT. 1999b. NBR 14340: Água - Determinação da condutividade e da resistividade elétrica. Rio de Janeiro: ABNT.

BARBOSA, FAR. and PADISÁK, J. 2004. Consideraçôes sobre desenho amostral para estudos de longa duração. In BICUDO, CEM. and BICUDO, DC., orgs. Amostragem em Limnologia. São Carlos: Rima. p. 343-351.

BELLINGER, EG. and SIGEE, DC. 2010. Freshwater algae: identification and use as bioindicators. WilleyChichester: Blackwell.

BENDATI, MM., SCHWARZBACH, MSR., MAIZONAVE, CRM., ALMEIDA, LB. and BRINGHENTI, ML. 2003. Avaliação da qualidade da água do Lago Guaiba: subsídios para a gestão da bacia hidrográfica. Ecos Pesquisa, vol. 4, no. 7, p. 34.

BICUDO, CEM. and BICUDO, RMT. 1970. Algas de águas continentais do Brasil: chave ilustrada para identificação de gêneros. São Paulo: Fundação Brasileira para o Desenvolvimento do Ensino de Ciências/EDUSP.

BICUDO, CEM. and MENEZES, M. 2005. Gêneros de algas continentais do Brasil: chave para identificação e descriçôes. São Carlos: Rima.

BICUDO, DC., FERRAGUT, C., CROSSETTI, LO. and BICUDO, CEM. 2006. Efeitos do represamento 
sobre a estrutura da comunidade fitoplanctônica do reservatório de Rosana, baixo rio Paranapanema, Estado de São Paulo. In NOGUEIRA, MG., HENRY, R. and JORCIN, A., orgs. Ecologia de reservatórios: impactos potenciais, ações de manejo e sistemas em cascata. São Carlos: Rima. p. 349-377.

BOURRELLY, P. 1970. Les algues d'eau douce: initiation a la systematique. Tome III: Les algues bleues et rouges, Les Euglenins, Peridiniens et Cryptomonadines. Paris: Boubee Ed. and Cie Paris.

BOURRELLY, P. 1972. Les algues d'eau douce: initiation a la systematique. Tome I: Les algues vertes. Paris: Boubee Ed. and Cie Paris.

BOURRELLY, P. 1981. Les algues d'eau douce: initiation a la systematique. Tome II: Les algues jaunes et brunes. Chrysophycees, Phaeophycees, Xanthophycees et Diatomees. Paris: Boubee Ed. and Cie Paris.

COLE, GA. 1994. Textbook of Lymnology. Illinois: Waveland Press.

DEMIR, N. and ATAY, D. 2002. The treatment efficiency of plankton in the Ivedik drinking water treatment plant, Ankara. Turkish Journal of Biology, vol. 26, no. 4, p. 229-234.

DEVERCELLI, M. 2006. Phytoplankton of middle Paraná river during an anomalous hydrological period: a morphological and functional approach. Hydrobiologia, vol. 563, p. 465-478. http://dx.doi. org/10.1007/s10750-006-0036-0

ELLIOTT, JM. 1990. The need for long-term investigation in ecology and the contribution of the Freshwater Biological Association. Freshwater Biology, vol. 23, no. 1, p. 1-5. http://dx.doi. org/10.1111/j.1365-2427.1990.tb00250.x

FARIA, CM. and LERSCH, EC. 2001. Monitoramento das águas do Delta e foz dos rios formadores do Guaíba. Ecos Pesquisa, no. 5, p. 1-63.

HAMMER, Ø., HARPER, DAT. and RYAN, PD. 2001. Past: paleontological statistics software package for education and data analysis. Palaeontologia Electronica, vol. 4, no. 1, p. 1-9.

HUSZAR, VLM. 1996. Floristic composition and biogeographical aspects of the phytoplankton of an amazonian flood-plain lake (lake Batata, Pará, Brazil). Acta Limnologica Brasiliensia, vol. 8, p. 127-136.

HUSZAR, VLM., BICUDO, DC., GIANI, A., FERRAGUT, C., MARTINELLI, LA. and HENRY, R. 2005. Subsídios para a compreensão sobre a limitaçáo de nutrientes ao crescimento do fitoplâncton e do perifíton em ecossistemas continentais lênticos do Brasil. In ROLAND, F., CESAR, D. and MARINHO, M., orgs. Liçōes de Limnologia. São Carlos: Rima. p. 243-260.

ISTVÁNOVICS, V. 2009. Eutrophication of lakes and reservoirs. In LIKENS, GE., ed. Plankton of Inland Waters: a derivative of Encyclopedia of Inland Waters. San Diego: Elsevier. p. 316-324.
KLAVENESS, D. 1988. Ecology of the Cryptomonadida: a first review. In SANDGREN, CD., ed. Growth and reproductive strategies of freshwater phytoplankton. Cambridge: Cambridge University Press. p. 105-133.

KÖPPEN, W. 1948. Climatología: um studio de los climas de la tierra. Mexico: Fondo de Cultura Economica del Mexico.

LIVI, P. 1998. Elementos do clima: o contraste dos tempos frios e quentes. In MENEGAT, R., PORTO, ML., CARRARO, CC. and FERNANDES, LAD., ed. Atlas Ambiental de Porto Alegre. Porto Alegre: Ed. da UFRGS. p. 73-78.

MAIZONAVE, CRM., ANDRADE, RR., THEWES, MR. and SCHERER, KD. 2009. Florações de algas e cianobactérias no lago Guaiba: série histórica do Dmae de Porto Alegre, RS. Ecos Técnica, no. 2, p. 5-14.

MCGOWAN, S., BARKER, P., HAWORTH, EY., LEAVITT, PR., MABERLY, SC. and PATES, J. 2012. Humans and climates as drivers of algal community change in Windermere since 1850 . Freshwater Biology, vol. 57, no. 2, p. 260-277. http:// dx.doi.org/10.1111/j.1365-2427.2011.02689.x

MENDONÇA, F. and DANNI-OLIVEIRA, IM. 2007. Climatologia: noçóes básicas e climas no Brasil. São Paulo: Oficinas de Textos.

MÜLLER, CC., RAYA-RODRIGUEZ, MT. and CYBIS, LF. 2010. Diagnóstico da qualidade analítica na quantificação de cianobactérias. Engenharia Sanitária e Ambiental, vol. 15, no. 3, p. 283-290. http://dx.doi. org/10.1590/S1413-41522010000300012

NICOLODI, JL., TOLDO JÚNIOR, EE. and FARINA, L. 2010. Dinâmica e ressuspensão por ondas no Lago Guaiba (RS, Brasil) e implicaçóes nos locais de captação de água para abastecimento humano. Pesquisas em Geociências, vol. 37, no. 1, p. 25-39.

NORONHA, LC. 1998. Baía de todas as águas: preservação e gerenciamento ambiental na bacia hidrográfica do Guaiba. Porto Alegre: Secretaria Executiva do Pró-Guaíba.

Organisation for Economic Cooperation and Development - OECD. 1982. Eutrophication of waters: monitoring, assessment and control. Paris: OECD.

PADISÁK, J., BÓRICS, G., GRIGORSZKY, I. and SORÓCZKI-PINTÉR, É. 2006. Use of phytoplankton assemblagles for monitoring ecological status of lakes within the water framework directive: the assemblage index. Hydrobiologia, vol. 553, no. 1, p. 1-14. http://dx.doi.org/10.1007/s10750-0051393-9

PADISÁK, J., CROSSETTI, LO. and NASELLIFLORES, L. 2009. Use and misuse in the application of the phytoplankton functional classification: a critical review with updates. Hydrobiologia, vol. 621, 
no. 1, p.1-19. http://dx.doi.org/10.1007/s10750008-9645-0

PAERL, HW. 1988. Growth and reproductive strategies of freshwater blue-green algae (cyanobacteria). In SANDGREN, CD., ed. Growth and reproductive strategies of freshwater phytoplankton. Cambridge: Cambridge University Press. p. 261-315.

REYNOLDS, CS. 1988. Functional morphology and the adaptative strategies of freshwater phytoplankton. In SANDGREN, CD., ed. Growth and reproductive strategies of freshwater phytoplankton. Cambridge: Cambridge University Press. p. 388-433.

REYNOLDS, CS., HUSZAR, V., KRUK, C., NASELLI-FLORES, L. and MELO, S. 2002. Towards a functional classification of the freshwater phytoplankton. Journal of Plankton Research, vol. 24, no. 5, p. 417-428. http://dx.doi.org/10.1093/ plankt/24.5.417

REYNOLDS, CS. 2006. Ecology of Phytoplankton. Cambridge: Cambridge University Press.

RIBEIRO, GF., ANDRADE, RR., MAIZONAVE, CRM. and CROSSETTI, LO. 2012. Effects of cyanobacterial summer bloom on the phytoplankton structure in an urban shallow lake, Guaiba Lake, southern Brazil. Neotropical Biology and Conservation, vol. 7 , no. 2 , p. 78-87.

RODRIGUES, LC., TRAIN, S., PIVATO, BM., BOVO, VM., BORGES, PAF. and JATI, S. 2005. Assembléias fitoplanctônicas de trinta reservatórios do estado do Paraná. In RODRIGUES, L., THOMAZ, SM., AGOSTINHO, AA. and GOMES, LC., eds. Biocenoses em reservatórios: padróes espaciais e temporais. São Carlos: Rima. p. 57-72.

RODRIGUES, SC., TORGAN, L. and SCHWARZBOLD, A. 2007. Composição e variação sazonal do fitoplâncton na foz dos rios do Delta do Jacuí, RS, Brasil. Acta Botanica Brasílica, vol. 21, no. 3, p. 707-721. http://dx.doi.org/10.1590/S010233062007000300017

SANT'ANNA, CL., AZEVEDO, MTP., WERNER, VR., DOGO, CR., RIOS, FR. and CARVALHO, LR. 2008. Review of toxic species of Cyanobacteria in Brazil. Algologicalstudies, vol. 126, p. 251-265. http:// dx.doi.org/10.1127/1864-1318/2008/0126-0251

SEELIGER, U., CORDAZZO, CE. and BARBOSA, FAR. 2002. Os sites e o programa brasileiro de pesquisas ecológicas de longa duração. Belo Horizonte: FUFRS/ UFMG.
SOMMER, U. 1988. Growth and survival strategies of planktonic diatoms. In SANDGREN, CD., ed. Growth and reproductive strategies of freshwater phytoplankton. Cambridge: Cambridge University Press. p. 227-260.

TELL, G., O'FARRELL, I. and LOMBARDO, RJ. 2005. Euglenoid morphospecies replacement along a hydraulic gradient of Lower Paraná Basin (Argentina). Freshwater Biology, vol. 50, no. 4, p. 616-626. http:// dx.doi.org/10.1111/j.1365-2427.2005.01347.x

TERRA, NR., FEIDEN, IR. and FACHEL, JMG. 2009. Monitoring of a swamp river contaminated by multiple waste. Acta Limnologica Brasiliensia, vol. 21, no. 1 , p. 79-88.

TUNDISI, JG., TUNDISI, TM. and GALLI, CS. 2006. Eutrophication in South America: causes, consequences and technologies for management and control. São Carlos: International Institute of Ecology.

United States Environmental Protection Agency - USEPA. 1986. Method 300.7: Dissolved sodium, ammnonium, potassium, magnesium and calcium in wet deposition by chemically suppressed ion chromatography. Atlanta: USEPA.

United States Environmental Protection Agency - USEPA. 1993. Method 300.0: Determination of inorganic anions by ion chromatography. Atlanta: USEPA.

VALDES-WEAVER, LM., PIEHLER, MF., PINCKNEY, JL., HOWE, KE., ROSSIGNOL, K. and PAERL, HW. 2006. Long-term temporal and spatial trends in phytoplankton biomass and class-level taxonomic composition in the hydrologically variable NeusePamlico estuarine continuum, North Carolina, U.S.A. Limnology and Oceanography, vol. 51, no. 3, p. 1410-1420. http://dx.doi.org/10.4319/ lo.2006.51.3.1410

VAN DEN HOEK, C., MANN, DG. and JAHNS, HM. 1995. Algae: An introduction to phycology. Cambridge: Cambridge University Press.

VIEIRA, EF. and RANGEL, SRS. 1988. Planície costeira do Rio Grande do Sul: geografia física, vegetação e dinâmica sócio-demográfica. Porto Alegre: Sagra.

VOLLENWEIDER, RA. 1974. A manual on methods for measuring primary production in aquatic environments. Oxford: Blackwell Science Publications.

WETZEL, RG. 1983. Limnologia. Lisboa: Fundação Calouste Gulbenkian. 